\title{
Research on The Reform of Talent Training Mode in Colleges and Universities
}

\author{
Sai Qiao \\ Department of Information Science and Technology, \\ Taishan University, \\ Taian 271000,China \\ tsuqiaosai@163.com
}

\begin{abstract}
According to the connotation of talent training mode, the extension of talent training mode should be the whole process of talent training. It is composed of five parts: the target of personnel training, the content of training, the system of training, the way of training and the evaluation of training. Under the guidance of certain educational theory and educational thought, according to the needs of economic and social development, we need to determine the target of personnel training, according to the goal of talent training to determine talents specifications and quality structure, on this basis, construct a talent training scheme, determine the teaching content and curriculum system of personnel training, implement the scientific teaching methods, methods and means, and establish a set of management and evaluation system to ensure the implementation of the training process.
\end{abstract}

Keywords_-Personnel training mode;Reform ;Colleges and universities ;Training target ;Culture system

\section{INTRODUCTION}

" Why do our schools always fail to cultivate outstanding talents? " this question, known as the" Qian Xuesen question ", aroused deep thought and attention from the premier to the common people after Qian Xuesen's death. Money always thinks that it is the pattern of cultivating talents, which leads us to cultivate not outstanding talents. What is the talent training mode? How to reform the talent training mode?

\section{THE CONNOTATION OF THE TALENT TRAINING MODE.}

Although there is talent training mode, but the talent training mode as a phrase in our country, only about 30 years of history. In 1983, wenyulin put forward the term " talent training mode" in the " reform talent training mode, according to subject setting ", and many educators have carried out the research successively, but the connotation is not clearly expressed. The earliest use of the concept of " talent training mode" by the state educational administration is the " ninth five - year plan" and the " ten - year plan" of the people's Republic of China, which was approved by the eighth people's congress at the fourth plenary session of the people's Republic of China in 1996. In 1997, Zhang Chen Zufu, then deputy director of education of the Ministry of education, in the" meeting the challenge of the times and renewing educational ideas and ideas " it pointed out," the so-called talent training mode refers to what kind of knowledge, ability, quality structure is built for the educated and how to realize this kind of structure. " in March 1998, Zhou yuanqing, then deputy minister of education, pointed out in the report of the first national general higher school teaching conference that" the so-called talent training model, in fact, is the training objectives, training specifications and basic training methods, it determines the basic characteristics of the talents cultivated in institutions of higher learning, and reflects the educational ideology and educational concept of higher education. Since then,the domestic scholars on the talent training mode of the exposition around this, some to enrich. 
To sum up, " talent training mode" refers to the total process of talent education, under the guidance of certain education theory and educational thought, according to specific training objectives, with relatively stable cultivation content, training system and evaluation mode. The talent training mode can also be understood as " what kind of people, how to cultivate people ".

\section{THE CONSTITUENT ELEMENTS OF TALENT CULTIVATION MODE.}

According to the connotation of talent training mode, the extension of talent training mode should be the whole process of talent training. It is composed of five parts: the target of personnel training, the content of training, the system of training, the way of training and the evaluation of training. Educators first, under the guidance of a certain educational theory and ideological guidance, according to the needs of economic and social development, determine the target of personnel training, according to the goal of talent training to determine talents specifications and quality structure, on this basis, build the talent training program, determine the teaching content and curriculum system of personnel training, and then implement the scientific teaching methods, methods and means, and establish a set of management and evaluation system to ensure the implementation of the training process.

\section{THE RESTRICTIVE FACTORS OF THE REFORM OF TALENT CULTIVATION MODE.}

\section{A. The restriction of educational thought.}

In determining what kind of talents, colleges and universities are mainly affected by three factors, which are the actual needs of the students themselves, social needs and the will of the educators. In the stage of professional education, the goal is mainly determined by the educational workers' will, pay attention to knowledge - based, pay attention to the disciplinary system and professional system, and pay little attention to the actual needs and social needs of students' development. With the realization of the popularization of higher education, the training talents gradually move towards the talent market, the demand of the society is more and more valued, but as the actual needs of the students themselves, due to the influence of traditional education thought, it has not received enough attention. Therefore, the traditional education thought is the biggest obstacle to establish the people oriented education idea, is the important restriction factor of the undergraduate talent training mode reform in our country at present.

\section{B. The restriction of teaching conditions.}

Teaching conditions include teachers, school buildings and books. Teachers are the key factors of the implementation of the elective system, the number of teachers is not enough to open enough courses, not enough courses, the choice of students is very small, the personalized learning needs are of course not to meet, the tutorial system will be just empty words. School - school is one of the most basic conditions of school, should not be the restricting factors of running a school, but the popularization of higher education in our country is too fast, so some schools can not meet the needs of the most basic school, students dormitory even can not accommodate all students; The number of seats in the classroom is insufficient, the structure is not reasonable to the teaching operation to bring great pressure, appeared the golden time of the students and teachers do not attend classes because there is no spare classroom. In the book, some schools in order to meet the undergraduate teaching level of the Ministry of education to evaluate the requirements of books, under the limited book purchase funds, only pay attention to quantity, quality and the needs of teachers and students are neglected, students can not borrow the books they want to borrow.

\section{The constraints of the teaching platform.}

Teaching platform includes professional, curriculum, laboratory, practice base and so on. The professional reflects the characteristics of the school, the number and structure of the professional determines the size and structure of the school, in the professional aspect, the first is whether the major is the students want to learn the major; The second is whether the professional training program provides enough space for students to learn, so that students can have a greater choice in the learning process; 
Thirdly, it can meet the needs of students to learn other disciplines knowledge, and build a platform for the cultivation of compound talents. Curriculum is the basic unit of teaching, is the core of the teaching reform, in the curriculum, the first is whether to open enough courses; Secondly, the content of the course teaching is to pay attention to the integrity of the subject system or the students' learning needs; Again is whether the students have conditional independent choice of courses. Experimental teaching can stimulate students' interest in learning, which is welcomed by the students, in the experimental teaching, the lack of resources, difficult to share and open is prominent problem, some experimental instruments are set by 1 person, to 2 people a group, to 3 people, 4 people a group, even more people, the effect cannot be guaranteed; The shortage of experimental teaching resources has even affected the teaching operation, which brings great difficulties to the curriculum arrangement. The enthusiasm of students to carry out innovative experiments is high. the question is whether schools have enough laboratories to open to students and whether there are enough time to open to students. With the expansion of students' scale, the practice teaching is gradually weakened, the main reason is the restriction of the practice teaching base. Students' practice often has a certain destructiveness, because the campus has arranged a large number of teachers scientific research projects, the off-campus base unit operation mode and planned economy period has changed significantly, and the teaching funds are insufficient, the number of students out of the school is less and less, the distance is more and more close, students' practical opportunities in the teaching base greatly reduced, the practical teaching effect is difficult to ensure.

\section{The restriction of the management system.}

Outside school, the education administrative department to the school unified death, the school autonomy limited, the professional establishment, the admission plan school basically has no say, the related administrative department management system does not sound limit the implementation of the credit system; The status of teaching work center is not prominent, leading to the reform of talent training mode is difficult to implement effectively, the number of teachers is not enough to achieve, teacher assessment system is not enough, teacher evaluation system is not enough, leading teachers in teaching, lack of quality teaching resources, students are difficult to choose students of interest, students' learning performance assessment process evaluation, leading to students lack of learning motivation and pressure, teachers classroom teaching quality evaluation system is too complex, leading students to cope with the phenomenon of simple evaluation.

\section{$\mathrm{V}$ DEEPENING THE REFORM OF PERSONNEL TRAINING MODE}

\section{A. The premise of the reform of personnel training mode is to establish the "people - oriented" educational philosophy.}

The basic function of education is to cultivate talents, and educators, regardless of the mode of training talents, must train a sound person, qualified people as the most basic starting point, dedicated to the cultivation of basic knowledge, ability and ethics as a natural person, as a social sense of social responsibility, as a professional professional skills. The fundamental purpose of the reform of talent training mode is to improve the quality of personnel training. Therefore, no matter which reform measures, must be conducive to the growth of students. Under the new situation, we need to carry out the reform of talent training mode under the guidance of new talent concept and new quality concept.

B. The starting point of the reform of personnel training mode is to determine the training objective of " comprehensive development and capacity - oriented".

The comprehensive development of moral, intellectual, intellectual, physical and moral education is an important criterion for the goal of education and training. " morality" is not only ideological and moral, but also political quality and social responsibility. " wisdom" is not only scientific cultural knowledge and skills, but also scientific attitude and exploration spirit; " body" is not only physical, physical and physical, but also sports knowledge and skills, healthy psychology and noble sentiments. The ability to focus on the social needs, to highlight the cultivation of college students' learning ability, innovation ability, practical ability and employability, to cultivate the various abilities of college students into every course, every link. 
C. The foundation of the reform of personnel training mode is to build the curriculum system and teaching content adapted to the training objectives.

Curriculum system is the basic framework of personnel training program. the construction of curriculum system should correctly deal with the relationship between traditional content and modern content, imparting knowledge and improving quality, foundation and application, inheritance and innovation, unity and diversity, and so on, to realize the transformation of rigid curriculum structure to diversified elasticity curriculum structure. Teaching content is the main carrier of talent cultivation, the construction of training content to integrate knowledge transfer and ability cultivation into one, integrating business training and quality education into one, integrating teaching and scientific research and production into one, integrating natural science and humanistic science into one, integrating personal growth and social responsibility as one.

\section{The focus of the reform of personnel training mode is to mobilize the enthusiasm of teaching and learning.}

The focus of the reform of talent training mode is to carry out all-round quality education, and the starting point is classroom teaching. Teachers should dare to challenge the full house, dare to challenge the exam, and do both teaching and fishing, both educating people and raising heart, consciously combine the thinking of thinking, the unity of knowledge and knowledge and the idea of teaching students in accordance with their aptitude to the whole process of teaching and educating. To cultivate students' professional interest through the contacts between high level professors and junior students; Through the implementation of student-centered teaching organization form and teaching methods, enhance students' learning initiative; To cultivate students' scientific spirit and scientific methods through the participation of students in the process of teachers' scientific research; Through the strengthening process examination, guide students to invest more energy; Through the management system reform, give students greater professional choice autonomy and more to read the second professional opportunities; Through the establishment of the learning - based evaluation of the tree first policy, advocate the atmosphere of learning as proud. We should guide teachers to improve the teaching content and methods through the actual needs of students' growth and development. By strengthening the evaluation of teaching process, teachers should be promoted to teach strictly and strengthen the management of teaching process. Encourage teachers to devote more energy to teaching through the development of incentive policies.

\section{E. The key to the reform of talent training mode is to establish a team of high quality teachers who love teaching.}

Teachers are the direct participants in the reform of talent training mode, and the teaching level of teachers determines the success or failure of the reform of personnel training mode. To reform the talent training mode, we must strengthen the construction of teaching echelon and ensure the number of teachers to meet the needs of running a school. On this basis, the implementation of the national regulations on teaching for undergraduate students without discount, the implementation of the teaching assistant system of young teachers, the social practice as the necessary conditions for the promotion of teachers' professional title, promote the young teachers to improve the teaching level and practical ability as soon as possible. Teachers take teaching as the bounden duty, through the in-depth study of teaching and learning to improve the ability of teaching and educating people, with noble ethics, personality charm, knowledge - style education infection students, as the guide and guide for students healthy growth.

The reform of talent training mode is the core content of deepening educational system reform, is the inevitable choice of the connotation development of higher education, is the " key" of improving the quality of higher education in our country at present, and the higher education can ensure the quality of personnel training is constantly improving only by grasping this " key point ".

\section{REFERENCES}

[1] Yanfeng Chen, "Research on the Reform of Mathematics Talents Training Mode and Curriculum System in Local Normal University", Advances in Computer Science Research, vol. A247, pp. 46-51, January 2016.

[2] Dou Y, Shi,Q-Z, "Research on computer foundation teaching system of non-computer major", Research in Teathing 32(1),67-70,2009.

[3] Guo Haixia,Xu Xiaoming,Jin Hao, "Reform Scheme Design of Innovative Talent Training Mode for Higher Education in Hebei Province”,Journal of Adult Education School of Hebei University of Technology,40-44,2009. 